\title{
UNITED STATES GEOPHYSICAL EXPEDITION TO THE PACIFIC OCEAN
}

\author{
By Prof. S. Chapman, F.R.S.
}

A NOTABLE expedition has been arranged by the National Geographic Society of America and the University of Virginia, with the co-operation of the United States Coast Guard, to undertake varied geophysical investigations in the Central and South Pacific Ocean. The expedition will start in September next, and its work will extend over a whole year. It will be transported by a 2,000-ton steel Coast Guard cutter, fitted with the latest type of sonic depth-finding appar-

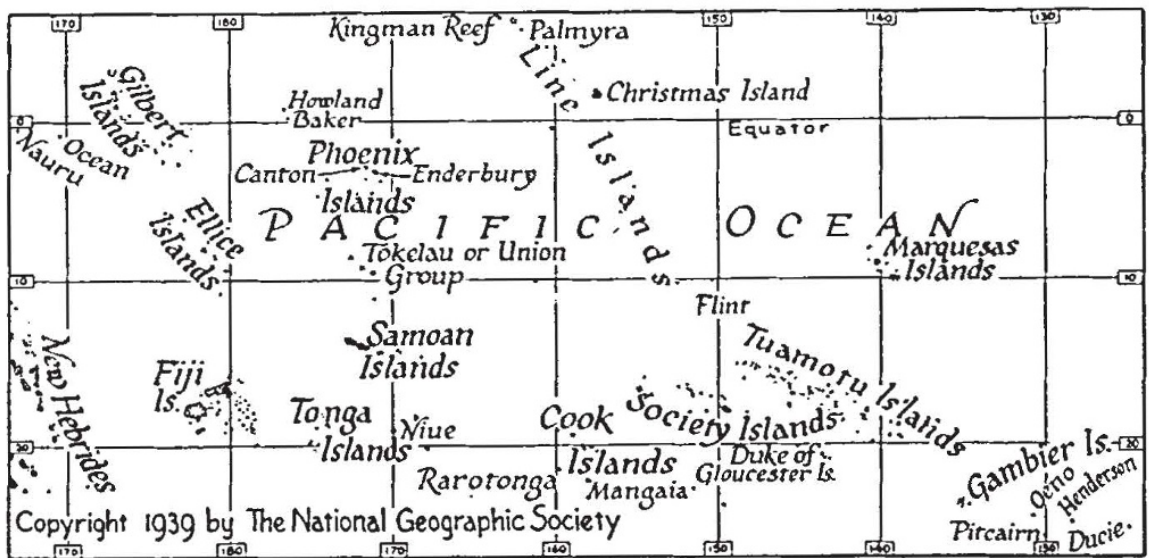

ship will put in at intervals at Honolulu and Auckland, Now Zealand, for supplies and mail. From time to time the expedition will send out radio broadcasts describing its progress.

The expedition will set up major bases on twenty or more islands, and from each major base will visit from ten to fifty other islands. All the islands except those of the Fiji and Tonga groups (which are of the 'continental' type, with a foundation of very old granite) are of the 'pure Pacific' type, either of recent volcanic origin, or of coral resting on recent underwater volcanic out. pourings.

Gravity determinations and magnetic observations, together with careful observations of latitude and longitude, will be made on the is. lands visited, and at the same time the geology of the islands will be studied : the region is virgin ground for the gravity survey, and of course atus, and carrying a two-seater scout observation seaplane which will be used in making aerial photo. graphs and island maps. While the scientific work is proceeding, the Coast Guard will make a survey of present and future needs for navigational and radio aids to marine and air commerce.

The expedition will range over an area of $4 \frac{1}{2}$ million square miles, south of the Hawaiian Islands, east of Australia and New Guinea and north-east of New Zealand ; most of its work will be done on the many islands scattered over this area. These islands are all owned or controlled by the United States of America, France, and Great Britain or the British Dominions; westernmost of those to be studied is Nauru, practically on the equator, about 800 miles north-east of Australia. Easternmost is Ducie Island, nearly in the longitude of San Francisco, almost on the tropic of Capricorn. The northern and southern limits of the area studied will be Kingman Reef (500 miles south of Honolulu) and Pitcairn Island. The expedition will sail from San Francisco, first visiting Canton Island, now under joint American and British control. During its twelve months in the field, the magnetic observations everywhere need to be repeated every decade or so in order to keep up to date ourknowledge of the earth's changing field. Artificial seismic waves will be set up by explosions on the ocean bed to indicate the types and depths of rock below; mud 'cores' will also be obtained, showing the composition, for a depth of several feet, of the top layer of the ocean floor. Observations on marine biology will be made, and radio engineers will accompany the expedition in order to investigate radio phenomena.

The expedition is thus one of the most important and extensive scientific exploration surveys undertaken by any country for many years : in several respects its programme coincides with that which was recently arranged, for work over a much more limited area (on or near the edge of the continental shelf off the British coasts), by the Royal Society with the co-operation of H.MI. Navy-though the completion of that survey was prevented by the political crisis of last September. It is greatly to be hoped that the plans for the proposed United States expedition may be carried through fully and successfully. 